\title{
How Are Creative Abilities Related to Meta-Learning Competences?
}

\author{
Beata Kunat \\ University of Bialystok, Poland \\ E-mail: b.kunat@uwb.edu.pl
}

\author{
Janina Uszyńska-Jarmoc \\ University of Bialystok, Poland \\ E-mail: j.uszynska@uwb.edu.pl
}

\author{
Monika Żak-Skalimowska \\ University of Bialystok, Poland \\ E-mail:m.zak@uwb.edu.pl
}

ARTICLE INFO

\section{Keywords:}

Pedagogy students

Competence

Creativity

Meta-learning

\section{Article history:}

Received 03 November 2018

Received in revised form 28 June 2019

Accepted 03 July 2019

ISSN: 2354-0036

DOI: 10.1515/ctra-2019-0005
A B S TR A C T

This correlational study explored the relationship between creative abilities and selected meta-learning competences. The study was conducted among 250 first-year undergraduate and graduate students who solved the Test for Creative Thinking - Drawing Production and filled in the My Learning Questionnaire. The results demonstrate a statistically significant correlation between students' awareness of their own learning and their creative abilities as well as a positive link between creative abilities and level of knowledge about human learning. These relationships were not moderated by the level of studies - the links among undergraduate and graduate students were similar in the case of self-awareness of learning and knowledge about learning.

\section{INTRODUCTION}

The main purpose of this study was to explore the relationship between creative abilities and selected meta-learning competences. More specifically, we were interested in exploring these links among future teachers. Indeed, researchers think of the process of the teacher's professional development in terms of lifelong learning and "becoming a teacher" (Beavers, 2009; Day, 2004; Duță \& Rafailă, 2014; Hammersley, 2006; Nicholls, 2000; Su, Feng, \& Hsu, 2017; Yuen Sze Goh, 2015). The need for the teacher's continual professional development is connected with the specific nature of this change-oriented profession (Day, 2004; Nicholls, 2010; Steffy, Wolfe, Pasch, \& Enz, 2000). Therefore, it seems vital that university teacher training programmes involve the preparation of creative teachers, open to new professional challenges (Abedini \& Broujeni, 2016; Beghetto \& Kaufman, 2009; Cochrane, Cockett, \& Cape, 2007; Davies, 2006; Jeffrey, 2006; Freun_\& Holling, 
2008; Wood \& Ashfield, 2008). Also important is the preparation of teachers who feel the need for lifelong learning and are aware of their own learning processes, i.e. have developed meta-learning competence (Biggs, 1985; Jackson, 2004).

Creativity and competence in meta-learning may be considered as uniquely human qualities developing throughout one's life. Both comprise sets of features which vary among individuals, change over time, and develop through experience.

\section{Creativity in teaching and learning}

There is a widely held assumption that to properly understand and support students' creativity and promote creative education, teachers should be creative themselves (Abedini \& Broujeni, 2016; Freund \&Holling, 2008; Karwowski, Gralewski, Lebuda, \& Wiśniewska, 2007; Gralewski, 2016). As illustrated by the notion of creative openings, creativity may be considered an opportunity for teachers' creative opening to social interactions (Beghetto, 2016). On the other hand, however, there are a number of studies that show that teachers often have a limited awareness of the creative potential of their pupils (Gralewski \& Karwowski, 2012; 2013). Hence, we posit that it is necessary to determine the creativity level of future teachers at the beginning of their academic career in order to plan further educational activities in this field. We have also theorized that in order to prepare creative teachers with the competences to recognize and stimulate the creative potential of their pupils, it is necessary to better understand the basic mechanisms of student creativity during their education.

Creativity researchers recognize that creativity can come in many forms (Beghetto \& Kaufman, 2007; Kaufman \& Beghetto, 2009). In the scientific literature, creativity is usually defined by reference to four notions: the process, the set of personality traits, the product and the social setting (Rhodes, 1961; Runco, 2004). In the field of education, creativity is usually equated with creative potential (Barbot, Besançon, \& Lubart, 2015; Dyson, Chang, Chen, Hsiung, Tseng, \& Chang, 2016; Karwowski, 2009; Runco, 2004, 2016; Runco \& Jaeger, 2012; Silvia, Christensen, \& Cotter, 2016). Going further, creativity is usually defined as a process of generating new products, original and valuable ideas, concepts and solutions (Amabile, 1996; Cropley, 1999; Szmidt, 2010) or a set of related and interdependent personal features such as creative abilities and attitudes, openness and independence (Karwowski, 2010). A large body of research shows that creativity is driven by certain personality traits such as a fearless attitude to the world, a sense of humour, self-confidence, but also the ability not take oneself and one's environment too seriously, fantasy, flexibility and openness, non-conformism and the willingness to take risks (Karwowski, 2009; Szmidt, 2007). 
In the presented study, the notion of creativity was narrowed down to creative abilities. It was assumed that creative abilities encompass intellectual properties, including the ability to create something new and original.

\section{Meta-learning}

Meta-learning refers to "being aware of and taking control of one's own learning" (Biggs, 1985 , p. 185). Meta-learning is also defined as acquiring knowledge about one's own learning process and learning in different contexts, developing attitudes and beliefs that the way in which we learn and control this process is the right one, adequate to our thinking and acting capabilities and skills. It also includes the ability to use other people's knowledge about learning (Jackson, 2004). The development of meta-learning skills involves understanding the way we learn, as well as having insight into our motivation and capacity to regulate our own learning process (Jackson, 2004). The category of metalearning is conceptually related to metacognition (Daghistani, 2015; Wells \& CartwrightHatton, 2004; Sariçam, 2015; Stevanovic, Lalic, Batinic, Damjanovic, \& Jovic, 2016). Metacognition is understood as thinking about thinking and awareness of one's own cognitive processes (Kelly \& Donaldson, 2016; Welling, 2007). Literature reviews show that students' meta-learning capacity is usually measured by Meyer's (2004) Reflections on Learning Inventory (Lindblom-Ylänne, 2004; Meyer, Ward, \& Latreille, 2009; Ward \& Meyer, 2010).

In the presented research, we operationalized meta-learning as acquiring knowledge about the essence and objectives of learning as well as its internal and external determinants. The structure of meta-learning combines such categories as: meta-knowledge, meta-thinking and metacognition. Moreover, it was assumed that meta-learning competence is an internally motivated, self-regulated and consciously and responsibly used ability to plan, organize, monitor and assess one's own learning process, its sources, outcomes and determinants. Therefore, the process of meta-learning leads to a better understanding of how humans learn and how the individual learns. An important role here is played by motivation and capacity to regulate one's own learning process (Jackson, 2004). Meta-learning is hardly possible without self-regulation (self-control, selfawareness), reflection, autonomy and responsibility. Meta-learning competence encompasses the intentional, internally-motivated and consciously undertaken cognitive activity of the learner, who seeks to understand and control his or her own thinking processes, understands memory processes, chooses the best learning methods depending on the current conditions and circumstances, organizes or co-organizes in the learners' commu- 
nity an optimum learning environment and, finally, perceives learning as a positive experience for themselves (Uszyńska-Jarmoc, 2015).

\section{The relationship between creativity and components of meta-learning}

While there is a scarcity of studies on the relation between creativity and meta-learning competence, a substantial body of research allows for inferring some predictions regarding the connection between creative abilities and relevant factors serving as the components of meta-learning competence. An obvious category that is related to learning skills and serves as their output is academic achievement. Many studies have demonstrated that there is a positive, yet modest link between creativity and academic achievement (Dollinger 2011; Freund \& Holling 2008; Gajda, 2016; Gajda, Karwowski, \& Beghetto 2017; Gralewski \& Karwowski, 2012). It has been demonstrated that the correlation between students' creativity and academic achievement differs at different stages of education (Gralewski \& Karwowski, 2012). In senior secondary and higher education schools, the strength of this relationship is generally higher and the effect size varies from low to moderate. Researchers point to the reasons why the relationship between creativity and academic achievement differs (Gajda, 2015). Intelligence is a key factor that seems to be involved in meta-learning processes. The studies which employed different methods of creativity and intelligence measurement have revealed differences in the intensity of the relationship between these two variables (Batey \& Furnham, 2006; Batey, Furnham, \& Safiullina, 2010; Jauk, Benedek, Dunst, \& Neubauer, 2013; Kim, 2005; Preckel, Holling, \& Wiese, 2006; Silvia, 2008). Another candidate factor that may inform the meta-learning process is motivation to learn (Jackson, 2004).

\section{METHOD}

The aim of the study was to determine the link between creativity and meta-learning competence and its components. This partially exploratory study was driven by the following research questions: what is the link between creativity and the meta-learning competence of pedagogy students? Are different components of meta-learning differently related to creative ability?

\section{Participants}

The study was conducted with a group of 250 Polish first-year students of pedagogy (15 males and 235 females) at the University of Bialystok (Poland). The participants were first-year undergraduate students (group A) and first-year graduate students (group B) of pedagogy. The average age of all subjects was 20.6. The average age of undergraduate students (group A) was 19.6 while for graduate students (group B) it was 20.6. 


\section{Test for Creative Thinking - Drawing Production (TCT-DP) test sheet $A$ and $B$}

Students' creative ability was measured by the Test for Creative Thinking - Drawing Production (Urban \& Jellen, 1996), test sheet A and B - in its Polish version (Matczak, Jaworowska, \& Stańczak, 2000). Urban's (1996) componential model of creativity provided the theoretical basis for the instrument. This instrument not only considers divergent, quantitative features but also aspects of quality such as "gestalt", composition and elaboration, as well as other components emphasized in the literature such as (mental) risk taking, unconventionality, affection and humour. On the test sheet, some special figural fragments are offered, which stimulate further drawing in a free and open, non-specified way. The students were asked to complete the uncompleted drawing somebody else had begun. The drawings were collected after completion, a maximum of 15 minutes being allowed for each drawing. The finished drawing product was rated by allocating points based on 14 evaluation criteria. The reliability of the Polish adaptation is $\alpha=.75$ (Matczak, Jaworowska, \& Stańczak, 2000) and in the current study, test reliability was even higher $(\alpha=.83)$. There is also compelling evidence for the validity of the TCT-DP (Dollinger, Urban, \& James, 2004; Urban, 2004).

\section{My Learning Questionnaire}

The 'My Learning Questionnaire' was developed by the authors of the current study. The first version the questionnaire consisted of 64 items. A study (Uszyńska-Jarmoc \& ŻakSkalimowska, 2015) on 648 university students resulted in a 3-factor solution. The factors were as follows: 1) self-awareness - identifying and understanding the key problems connected with one's own learning, 2) knowledge - the student's general knowledge about human learning, 3) attitudes - emotional and cognitive assessment of problems related to human learning and one's own learning. The final version of the questionnaire consisted of 25 items loading on three factors. However, because previous studies have demonstrated some problems with the reliability of the third factor, a shortened version of the questionnaire was used in the current investigation. The reliability of both scales was satisfactory: $\alpha=.71$ for self-awareness and $\alpha=.84$ for knowledge.

\section{RESULTS}

As in this study we relied on a modified version of the questionnaire, we started with a Confirmatory Factor Analysis (CFA) to confirm the questionnaire's structure, which yielded the following results: $C F I=.918$ (comparative fit index); $T L I=.907$ (Tucker-Lewis index) and a RMSEA = .042 (root mean square error of approximation). All the factor loadings were relatively high and statistically significant. These findings indicate that the model describes the structure of the data well (Table 1). 
As a result of the modeling two constructs (latent variables) were identified: 1) selfawareness of learning - identifying and understanding the most important problems related to one's learning, 2) general scientific knowledge about human learning. The correlation between the latent factors was robust and significant $(r=.70, p<.001)$.

Table 1

Factor Loadings of the Modified 'My Learning Questionnaire'

I organize my learning process in such a way as to overcome my weak points or deficits.

If I have to master a large amount of material, I plan my learning process and schedule it over a number of days.

I can accurately assess my level of knowledge and lack of knowledge.

I am determined and show perseverance in the learning process.

I can control my emotions during learning, therefore I am able to concentrate on what I have to learn.

I know about different learning styles, so I select them in such a way as to be most effective for me at a given moment.

I know which aspects of the learning process I am good at, I am aware of my possibilities and I take advantage of them.

When I set myself goals and plan my learning, I am realistic in taking into account my possibilities for getting into the subject.

I understand what and how I am learning.

I like difficult challenges in the learning process and take them on willingly.

In spite of many attempts, I am unable to describe the best conditions for optimal learning.

I am able to reconcile the time I spend on learning and free time.

I know in what way I remember information most effectively.

Before starting to study, I take account of all the factors that might be distracting and eliminate them.

The brain continuously forms new neuronal connections, leaving memory traces.

I have a great deal of knowledge about the functioning of the human brain.

I am aware of the types of intelligence that I possess to a greater or lesser extent.

When organizing my learning processes I take into account theoretical (scientific) knowledge about how the brain learns.

I know that knowledge about how the brain learns is important in the learning process - and so I seek out scientific knowledge in this area.

I take advantage of every occasion to enrich my knowledge in the area of learning, and so I talk about this with my teachers, professors and friends. 
Descriptive statistics of TCT-DP scores are presented separately for both test sheet versions ( $A$ and $B$ ) as well as for the overall, aggregated score (see Table 2). The results of the student creativity tests show lack of clear differences in creativity levels measured with both test sheet versions ( $A$ and $B$ ) of the TCT-DP. The correlation between version $A$ and $B$ is $r=.66(p<.001)$, thus showing the high reliability of both versions.

Table 2

Descriptive Statistics for the Instruments Used in the Study

\begin{tabular}{lccccccc}
\hline & $\mathbf{N}$ & $\mathbf{M}$ & SD & Skewness & Kurtosis & Min. & Max. \\
\hline TCT-DP & & & & & & & \\
Version A & 250 & 26.7 & 10.9 & .473 & -.348 & 8 & 57 \\
Version B & 250 & 27.2 & 12.1 & .465 & -.431 & 7 & 63 \\
Total (A and B) & 250 & 53.8 & 21.0 & .497 & -.266 & 15 & 113 \\
My Learning Questionnaire & & & & & & & \\
Self-awareness of learning & 250 & 29.71 & 5.76 & -.251 & -.291 & 14 & 41 \\
Scientific knowledge about & 250 & 11.74 & 3.18 & .125 & .197 & 3 & 20 \\
\hline
\end{tabular}

The Relationship between Creativity and Components of Meta-learning

Consistent with our expectations the two dimensions of meta-learning were related to the creative abilities of students. We emphasize, however, that although the correlations were statistically significant, the effect size of these links was weak (Table 3).

Table 3

The Links Between Creative Abilities and Meta-learning Components

\begin{tabular}{llll}
\hline Subscales of meta-learning & $\begin{array}{l}\text { TCT-DP } \\
\text { version A }\end{array}$ & $\begin{array}{l}\text { TCT-DP } \\
\text { version } \\
\text { B }\end{array}$ & $\begin{array}{l}\text { TCT-DP } \\
\text { version A\&B }\end{array}$ \\
\hline self-awareness of learning & $.142^{*}$ & $.192^{\star *}$ & $.185^{\star *}$ \\
scientific knowledge about human learning & .035 & $.136^{*}$ & .097 \\
\hline
\end{tabular}

Note: ${ }^{*} p<.05,{ }^{* *} p<.001$

Of note, the link between characteristics of meta-learning and creative abilities were not moderated by the level of studies - the links among undergraduate and graduate students were similar in the case of self-awareness of learning (interaction term's $p=.78$ ) and knowledge about learning (interaction term's $p=.35$ ) (see Figure 1). 
TCT-DP and Self-Awareness of Learning

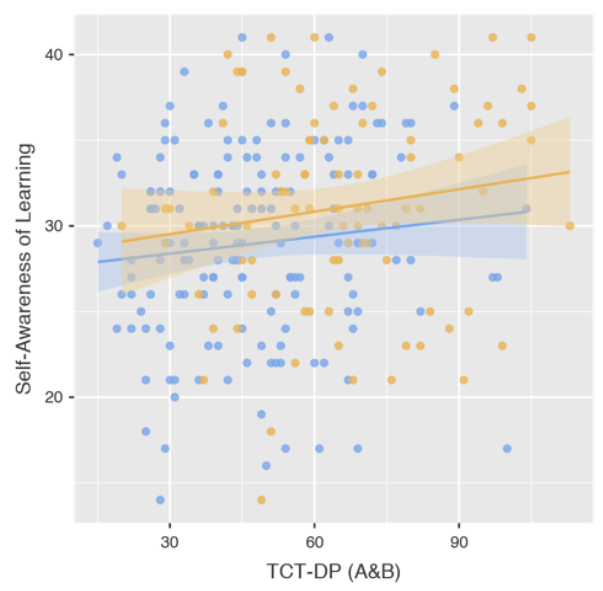

TCT-DP and Knowledge About Learning

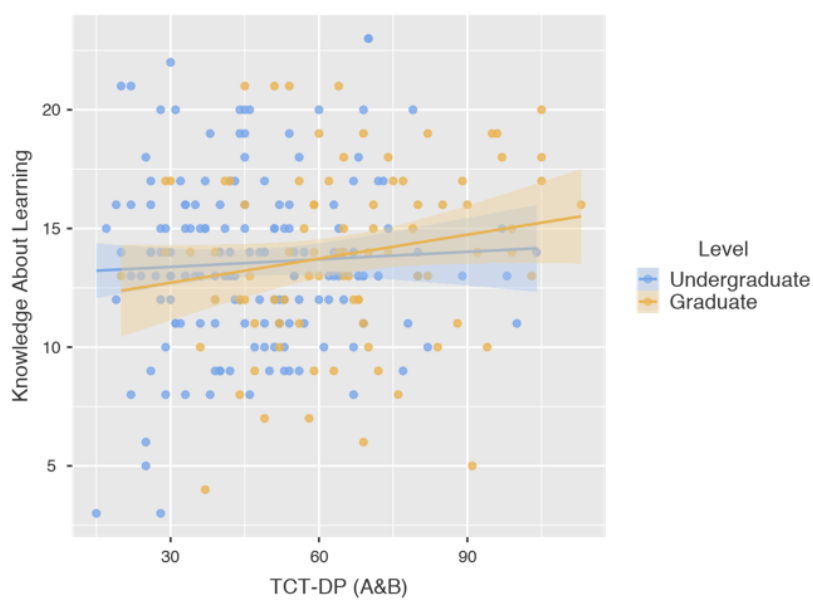

Figure 1. The links between creative abilities (total score on TCT-DP A and B) and components of meta-learning among undergraduate and graduate students.

\section{DISCUSSION AND CONCLUSIONS}

This study largely confirms the hypothesis that there is a positive relationship between creative abilities and meta-learning competences among pedagogy students. Although not impressive in terms of the effect size, the correlation was indeed statistically significant, suggesting that these two characteristics may be associated.

The correlation between creativity and components of meta-learning competences have been previously hypothesized, but although creativity researchers have demonstrated that there is a relationship between creativity and academic achievement (i.e. Dollinger 2011; Freund \& Holling, 2008; Gajda, 2016; Gralewski \& Karwowski, 2012; Gajda, Karwowski, \& Beghetto, 2017) this was not a direct test of the reasoning explored in this study.

The positive relationship between creative abilities and meta-learning competences among pedagogy students may arise as a result of the fact that creative individuals are cognitively more flexible (Baas, Roskes, Sligte, Nijstad, \& De Dreu, 2013; Zabelina \& Robinson, 2010). As a result, they may possess more self-awareness and may be more aware of their learning competencies. Creative people are usually more open and inquisitive, and at the same time, demonstrate greater autonomy. Therefore, the higher the level of creativity, the more aware they are of their own learning processes. Creativity is helpful in learning, as creative people are cognitively more curious and open to new challenges. Other research shows that there is a relationship between possessing knowledge in the area of metacognition, as well as skills in regulating cognitive processes and human creativity (Puryear, 2015). A significant ability of creative people is possessing declarative knowledge in the area of learning and acquiring knowledge, which is related to having an awareness of one's strong and weak points, as well as the appropri- 
ate skills for regulating them (Puryear, 2015). Creative persons are able to take advantage of the ability to develop a deeper analysis and achieve greater problem verification thanks to their awareness of metacognitive strategies. Research demonstrates that there is a relationship between conscious and controlled human learning (metacognition) and the person's characteristics as evidenced in the process of intentional learning (Kelly \& Donaldson, 2016).

Furthermore, in the present research study it was assumed that creativity and the meta-learning competence of pedagogy students are devlopmental in nature, and that as a result of having studied for longer, and preparing for entering the teaching profession, graduate students should also demonstrate higher levels of creativity as well as metalearning competencies in comparison to undergraduates. Differences of this kind, however, were not found in the study.

\section{Limitations and future studies}

Due to the fact that the study was conducted on a small group of pedagogy students at one university, its representativeness for the whole student population is obviously limited. Therefore future studies, optimally longitudinal in nature, are needed to replicate and extend these findings. We also believe that more dynamic - qualitative and observational studies in students' natural surroundings are needed to better understand the intersections of creativity and meta-learning, as well as their development.

\section{Recommendations}

The creativity of pedagogy students and their meta-learning competence have potential for development. These skills can be improved in the process of their university education if they are provided with appropriate conditions conducive to creative learning. As Beghetto and Kaufman (2009, p. 297) mentioned: „Academic learning and creativity should be overlapping goals that can be simultaneously pursued in programs of advanced academics". The syllabi of particular courses in the curriculum for pedagogy students should include elements aiming at developing students' creativity in the area of cognition, cognition and motivation and action. Educational situations fostering creative thinking (fluency, flexibility, originality) should be created. It is vital to stimulate divergent thinking in pedagogy students and develop their ability to generate many solutions and ideas. It is very important to include activities aimed at developing the openness of future teachers to new ideas and experience in the process of teacher training, stimulating their cognitive curiosity and readiness to undertake new tasks and face professional challenges. Moreover, meta-learning competence should be developed from the first year of studies. Students should be prepared to take over the control over their own learning (Biggs, 1985). In this context, we should develop students' knowledge about their own learning 
processes and learning in different contexts based on their own capacity and skills, their ability to think and act and to use other people's knowledge about learning (Jackson, 2004). Therefore, it is useful to introduce "how to learn" courses to the curriculum. Additionally, students should be encouraged to create social and digital networks for team learning. Also, the methods of learning outcome verification could be modified, e.g. exams and tests verifying only learning outcomes could be replaced with portfolio preparation.

\section{REFERENCES}

Abedini, S. \& Broujeni, R. B. (2016). Teacher Creativity in University Students' Views: A Content Analysis. International Journal of Pharmaceutical Research \& Allied Sciences, 5, 379-386.

Amabile, T. M. (1996). Creativity in Context. Boulder, CO: Westview.

Baas, M., Roskes, M., Sligte, D., Nijstad, B. A., \& De Dreu, C. K. W. (2013). Personality and creativity: The Dual Pathway to Creativity Model and a research agenda. Social and Personality Psychology Compass, 7, 732-748. DOI:10.1111/spc3.12062

Barbot, B., Besançon, M., \& Lubart, T. (2015). Creative potential in educational settings: Its nature, measure, and nurture. Education, 3-13, 43, 371-381.

Batey, M. \& Furnham, A. (2006). Creativity, intelligence, and personality: a critical review of the scattered literature. Genetic and General Psychology Monographs, 132, 355-429.

Batey, M., Furnham, A., \& Safiullina, X. (2010). Intelligence, general knowledge and personality as predictors of creativity. Learning and Individual Differences, 20, 532-535.

Beavers, A. (2009). Teachers as Learners: Implications of Adult Education for Professional Development. Journal of College Teaching \& Learning, 6, 25-30.

Beghetto, R. A. \& Kaufman, J. C. (2009). Intellectual Estuaries: Connecting Learning and Creativity in Programs of Advanced Academics. Journal of Advanced Academics, 20, 296-324.

Beghetto, R. A. (2016). Creative learning: A fresh look. Journal of Cognitive Education and Psychology, 15, 6 - 23.

Beghetto, R. A., \& Kaufman, J. C. (2007). Toward a broader conception of creativity: A case for 'mini-c' creativity. Psychology of Aesthetics, Creativity, and the Arts, 1, 73-79.

Biggs, J. B. (1985). The role of metalearning in study processes. British Journal of Educational Psychology, 55, 185-212.

Cochrane, P., Cockett, M., \& Cape, U. K. (2007). Building a creative school: A dynamic approach to school development. Stoke-on-Trent: Trentham.

Cropley, A.J. (1999). Creativity and cognition: Producing effective novelty. Roeper Review, 21, 253-260. 
Daghistani, M. (2015). Level of Need for Cognition and Metacognitive Thinking among Undergraduate Kindergarten Female Students at King Saud University in Saudi Arabia. Education, 136, 101-111.

Davies, T. (2006). Creative teaching and learning in Europe: Promoting a new paradigm. Cambridge Journal of Education, 36, 399-414.

Day, Ch. (2004). Rozwój zawodowy nauczyciela. Uczenie się przez całe życie. [Developing Teachers. The Challenges of Lifelong Learning]. Gdańsk: GWP.

Dollinger, S. J. (2011). "Standardized Minds" or Individuality? Admissions Tests and Creativity Revisited. Psychology of Aesthetics, Creativity, and the Arts, 5(4), 329-341.

Dollinger, S. J., Urban, K. K., \& James, T. A. (2004). Creativity and openness: further validation of two creative product measures. Creativity Research Journal, 16, 35-47.

Duță, N. \& Rafailă, E. (2014). Importance of the Lifelong Learning for Professional Development of University Teachers - Needs and Practical Implications. Procedia - Social and Behavioral Sciences, 127, 801-806. DOI: https://doi.org/10.1016/j.sbspro.2014.03.358

Dyson, S. B., Chang, Y. L., Chen, H C., Hsiung, H. Y., Tseng, C. C., \& Chang, J. H. (2016). The effect of tabletop role-playing games on the creative potential and emotional creativity of Taiwanese college students. Thinking Skills and Creativity, 19, 8896. DOI: 10.1016/j.tsc.2015.10.004

Freund, P. A. \& Holling, H. (2008). Creativity in the Classroom: A Multilevel Analysis Investigating the Impact of Creativity and Reasoning Ability on GPA. Creativity Research Journal, 20, 309-318.

Gajda, A. (2015). Osiągnięcia szkolne i kreatywność - w poszukiwaniu przyczyn zróżnicowania relacji. [School achievement and creativity - in search of reasons for differentiation of the relationship]. Teraźniejszość - Człowiek - Edukacja, [The Present the Human Being - Education], 2, 55-78.

Gajda, A. (2016). The relationship between school achievement and creativity at different educational stages. Thinking Skills and Creativity, 19, 246-259. DOI: 10.1016/ j.tsc.2015.12.004

Gajda, A., Karwowski, M., \& Beghetto R. A. (2017). Creativity and academic achievement: A meta-analysis. Journal of Educational Psychology,109, 269-299.

Gralewski, J. \& Karwowski, M. (2012). Creativity and school grades: A case from Poland. Thinking Skills and Creativity, 7, 198-208.

Gralewski, J. \& Karwowski, M. (2013). Polite girls and creative boys? Students' gender moderates accuracy of teachers' ratings of creativity. Journal of Creative Behavior, 47, 290-304. 
Gralewski, J. (2016). Teachers' Beliefs About Creativity and the Possibilities of Developing it in Polish High Schools: A Qualitative Study. Creativity Theories - Research Applications, 3, 292-329.

Hammersley, M. (2006). On the Teacher as Researcher. Educational Action Research, 1, 425-445. DOI:10.1080/0965079930010308

Jackson, N. (2004). Developing the concept of metalearning. Innovations in Education and Teaching International,41, 391-403.

Jauk, E., Benedek, M., Dunst, B., \& Neubauer, A. C. (2013). The relationship between intelligence and creativity: New support for the threshold hypothesis by means of empirical breakpoint detection. Intelligence, 4, 212-221.

Jeffrey, B. (2006). Creative teaching and learning: Towards a common discourse and practice. The Curriculum Journal, 17, 37-57.

Karwowski, M. (2009). Zgłębianie kreatywności. Studia nad pomiarem poziomu i stylu twórczości. [Penetrating creativity. Studies on measuring the level and style of creativity]. Warsaw: Special Pedagogy Academy Publishers.

Karwowski, M. (2010). Kreatywność - feeria rozumień, uwikłań, powodów. Teoretycznoempiryczna prolegomena. [Creativity - a feast of understanding, entanglements, reasons. Theoretico-empirical prolegomena]. In M. Karwowski, A. Gajda (Eds.), Kreatywność (nie tylko) w klasie szkolnej. [Creativity (not only) in school classes]. (pp. 12-44). Warsaw: Special Pedagogy Academy Publishers].

Karwowski, M., Gralewski, J., Lebuda, I., \& Wiśniewska, E. (2007). Creative teaching of creativity teachers: Polish perspective. Thinking Skills and Creativity, 2, 57-61.

Kelly, D. \& Donaldson, D. (2016). Investigating the complexities of academic success: Personality constrains the effects of metacognition. The Psychology of Education Review, 40, 17-24.

Kim, K. H. (2005). Can only intelligent people be creative? Journal of Secondary Gifted Education, 16, 57-66.

Lindblom-Ylänne, S. (2004). Raising students' awareness of their approaches to study. Innovations in Education \& Teaching International, 41, 405-421.

Matczak, A., Jaworowska, A., \& Stańczak, J. (2000). Rysunkowy Test Twórczego Myślenia TCT-DP, K.K. Urbana i H.G. Jellena [Test of creative thinking - drawing production TCT-DP. K.K. Urban and H.G. Jellen]. Warszawa: Pracownia Testów Psychologicznych PTP.

Meyer, J. H. F. (2004). An introduction to the RoLI. Innovations in Education and Teaching International. (Special issue: Metalearning in Higher Education), 41, 491-497. 
Meyer, J. H. F., Ward, S. C., \& Latreille, P. (2009). Threshold concepts and metalearning capacity. International Review of Economics Education, 8, 132-154.

Nicholls, G. (2000). Professional development, teaching, and lifelong learning: the implications for higher education. International Journal of Lifelong Education, 19, 370-377, DOI:10.1080/02601370050110419

Preckel, F., Holling, H., \& Wiese, M. (2006). Relationship of intelligence and creativity in gifted and nongifted students: An investigation of threshold theory. Personality \& Individual Differences, 40, 159-170.

Puryear, J.S. (2015). Metacognition as a moderator of creative ideation and creative production. Creativity Research Journal, 18, 55-63.

Rhodes, M. (1961). An analysis of creativity. The Phi Delta Kappan, 42, 305-310.

Runco, M. A. (2003). Education for creative potential. Scandinavian Journal of Educational Research, 47, 317-324.

Runco, M. A. (2004). Creativity. Annual Review of Psychology, 55, 657-687.

Runco, M. A. (2016). Commentary: Overview of Developmental Perspectives on Creativity and the Realization of Potential. In B. Barbot (Ed.). Perspectives on creativity development. New Directions for Child \& Adolescent Development, Development, 151, 97-109.

Runco, M. A., \& Jaeger, G. J. 2012. "The standard definition of creativity." Creativity Research Journal, 24, 92-96. DOI: 10.1080/10400419.2012.650092

Sariçam, H. (2015). Metacognition and Happiness. The mediating Role of Perceived Stress. Studia Psychologica, 57, 271-283.

Silvia, P. J. (2008). Another look at creativity and intelligence: Exploring higher-order models and probable confounds. Personality and Individual Differences, 44, 1012-1021.

Silvia, P. J., Christensen, A. P., \& Cotter, K. N. (2016). Commentary: The Development of Creativity-Ability, Motivation, and Potential. In B. Barbot (Ed.). Perspectives on creativity development. New Directions for Child \& Adolescent Development, 151, 111119. DOI: $10.1002 /$ cad.20147

Steffy, B. E., Wolfe, M. P., Pasch, S. H., \& Enz, B. J. (2000). Life Cycle of the Career Teacher. Thousand Oaks, CA: Corwin.

Stevanovic, D., Lalic, B., Batinic, J., Damjanovic, R. \& Jovic, V. (2016). Metacognitions Questionnaire for Children: Development and Validation of the Serbian Version. Journal of Evidence-Based Psychotherapies, 16, 135-151.

Su, Y., Feng, L. \& Hsu, Ch. H. (2017). What influences teachers' commitment to a lifelong professional development programme? Reflections on teachers' perceptions. International Journal of Lifelong Education, 37, 184-198. DOI:10.1080/02601370.2017.1397786 Szmidt, K. J. (2007). Pedagogika twórczości. [Pedagogy of creativity]. Gdańsk: Gdańskie 
Wydawnictwo Psychologiczne.

Szmidt, K. J. (2010). ABC kreatywności. [ABC of creativity]. Warszawa: Difin.

Urban, K. K. (2004). Assessing creativity: the test for creative thinking - drawing production (TCT-DP) the concept, application, evaluation and international studies. Psychology Science, 46, 387-397.

Urban, K.K. \& Jellen, H.G. (1996). Test for Creative Thinking - Drawing Production (TCTDP). Lisse, Netherlands: Swets and Zeitlinger.

Uszyńska-Jarmoc, J. (2015). Poziom samooceny kompetencji metauczenia się i jej wymiarów a osiągnięcia szkolne uczniów klas pierwszych liceum [The level of selfesteem and competence in metalearning with its dimensions and educational achievement of first year high school students]. (pp. 141-161). In J. UszyńskaJarmoc, M. Bilewicz (Eds.). Kompetencje kluczowe dzieci i młodzieży. Teoria i badania. [Key competencies of children and young people. Theory and research]. Warsaw: Żak Academic Publishers.

Uszyńska-Jarmoc, J., Żak-Skalimowska, M. (2015). My Learning Questionnaire. (unpublished).

Ward S. C., \& Meyer J. H. F. (2010). Metalearning capacity and threshold concept engagement. Innovations in Education and Teaching International, 47, 369-378.

Welling, H. (2007). Four mental operations in creative cognition: The importance of abstraction. Creativity Research Journal, 19, 163-177.

Wells, A. \& Cartwright-Hatton, S. (2004). A short form of the metacognitions questionnaire: Properties of the MCQ-30. Behaviour Research and Therapy, 42, 385-396.

Wood, R. \& Ashfield, J. (2008). The use of the interactive whiteboard for creative teaching and learning in literacy and mathematics: A case study. British Journal of Educational Technology, 39, 84-96.

Yuen Sze Goh, A.(2015). An individual learning journey: learning as becoming a vocational teacher. International Journal of Lifelong Education, 34, 680 - 695. DOI:10.1080/02601370.2015.1096311

Zabelina, D. L., \& Robinson, M. D. (2010). Creativity as flexible cognitive control. Psychology of Aesthetics, Creativity, and the Arts, 4, 136-143. DOI: http:// dx.doi.org/10.1037/a0017379

Corresponding author at: Beata Kunat, Faculty of Pedagogy and Psychology, University of Bialystok, 20 Świerkowa St., 15-328 Bialystok, Poland.

E-mail: b.kunat@uwb.edu.pl

(C) Copyright by Faculty of Pedagogy and Psychology, University of Bialystok, 20 Swierkowa St., 15-328 Bialystok, Poland tel. +48857457283 